\title{
Yield Potential, Nutrient Uptake, Metal Fractionation and Effect on Soil Properties under Integrative Use of Varied C:N Ratio Composts, Fly Ash and Inorganic Fertilizer Nitrogen in Rice Grown on Inceptisol
}

\author{
S. R. Dar (Corresponding author) \\ International Rice Research Institute (CSISA Eastern UP Hub India) \\ CG Block NASC Complex, DPS Marg-Pusa, New Delhi 110012, India \\ E-mail: darshahnawaz78@rediffmail.com, s.rasool@cgiar.org
}

\section{T. Thomas}

SHIATS (Allahabad Agricultural Institute Deemed University, Christian Minority University)

Allahabad, Utarpardesh 211007, India

\section{J. C. Dagar}

Indian Council of Agricultural Research, DPS Marg-Pusa, New Delhi 110012, India

Hidayatullah Mir \& Asima Amin

Central Institute for Temperate Horticulture, Srinagar 190017, India

Vivek Shankar

Department of Soil Science, Choudhary Charan Singh Haryana Agriculture University

Hisar -125004, India

D. Singh

Central Soil Salinity Research Institute, Regional Research Station, Lucknow, UP 226005, India

\section{A. K. Pundir \& R. K. Malik}

International Rice Research Institute (CSISA Eastern UP Hub India), CG Block NASC Complex

DPS Marg-Pusa, New Delhi 110012, India

\section{Guru Prem Grover}

Krishi Vigyan Kendra, Ambala Haryana 133104, India

Received: January 9, 2012

doi:10.5539/jas.v4n6p206
Accepted: January 19, 2012 Online Published: April 26, 2012

URL: http://dx.doi.org/10.5539/jas.v4n6p206

\begin{abstract}
Field experiment was conducted to evaluate the effect of incorporating fly ash and spent mushroom composts of varied $\mathrm{C}: \mathrm{N}$ ratio with and without fertilizer nitrogen on yield, trace metal content, nitrogen uptake, metal fractions and soil properties. Fertilizer nitrogen, fly ash and white button spent mushroom compost of narrow $\mathrm{C}: \mathrm{N}$ ratio increased whereas oyster spent mushroom compost of wider $\mathrm{C}: \mathrm{N}$ ratio decreased the paddy and straw yield. $\mathrm{Cd}$ and Ni content in paddy and straw, in the treatment comprising oyster spent mushroom compost did
\end{abstract}


not vary significantly, however addition of fly ash or white button spent mushroom compost enhanced their content in paddy and straw. Zn content of paddy and straw in composts were higher as compared to fertilizer nitrogen, fly ash. Uptake of nitrogen by paddy and straw was higher under integrated nutrient treatments, however oyster spent mushroom compost resulted in initial nitrogen starvation, so reduction in nitrogen uptake. Compost mainly one with wider $\mathrm{C}: \mathrm{N}$ ratio has shown more influence on adsorption of metals especially $\mathrm{Zn}$. The exchangeable, organic matter bound and residual fractionation percentage were higher for $\mathrm{Cd}, \mathrm{Zn}$ and $\mathrm{Ni}$ respectively in compost, especially one with wider $\mathrm{C}: \mathrm{N}$ ratio.

Keywords: C:N ratio, Metal fractionation, Nutrient uptake, Inorganic fertilizer and fly ash

\section{Introduction}

The use of mineral fertilizers is the quickest and surest way of boosting crop production. However, their cost and other constraints frequently deter farmers from using them in recommended quantities and in a balanced proportion. As a consequences of this and other constraints there seems to be no option but to fully exploit potential alternative sources of plant nutrients. Complementary use of plant nutrients from waste material along with mineral fertilizers is of great importance for soil productivity (Roy, 1994; Low Ogbomo et al., 2011 and Ayeni, 2011).

Interest in coal residue research has been increasing with greater dependence on coal as a source of energy. India's total coal reserves are estimated to continue the supply for more than 100 years at present use of utilization (Sikka and Kansal, 1995). Land application of fly ash to agricultural crops may offer a sensible distributed waste recycling alternative to land fill disposal, provided that their positive value in crop growth can be demonstrated (Pankaj et al., 2010). Fly ash application have corrected plant nutritional deficiencies of B (Marten, 1971; Randsome and Dowdy, 1987) Mg (Hill and Camp, 1984), Mo (Elseewi et al., 1980), S (Hill and Camp, 1984), and Zn (Schnappinger et al., 1975). The physical structure of fly ash often consists of "hollow spheres" and these particles show an increased surface area capillary action and nutrient holding capacity (Fisher et al., 1976).

Recycling of organic wastes in the agricultural land brings in the much needed organic and mineral matter to the soil. Spent mushroom compost is a waste product of mushroom industry; it is made from a blend of natural products that can include poultry manure, wheat straw, paddy straw, cotton seed hulls etc. In additions to these bulky ingredients compositors add a variety of protein concentrates. Although this compost is no longer economical for growing consecutive mushroom after harvesting of mushroom, mushroom compost is a valuable soil amendments and source of nutrients for field crop production. The organic material with the different C:N ratios and biochemical compositions not only release nutrients at different pace (Azmal et al., 1996) but also provides specific metal binding sites from which metals are difficult to exchange (Stewart et al., 1998). So there is a great need to create awareness for the use of the organic wastes in combinations with fertilizer nitrogen and fly ash to explore its potentialities, discover its complexities, evaluate its behavior, asses its benefits and learn to adapt for greater benefits, profitability and sustainability in large areas and on the more crops. (Dar et al., 2009)

\section{Materials and Methods}

\subsection{Experimental Soil and Nutrient Sources Used}

A field experiment was conducted for the two years (2004 and 2005) with rice at the experimental farm of the college of Agriculture, Allahabad Agricultural Institute Deemed University, Allahabad, India. The soil was sandy loam in texture with low available N, P and micronutrients. Fly ash, spent mushroom composts i.e. white button spent mushroom compost (WBSMC) with narrow C:N ratio and oyster spent mushroom compost (OYSMC) with wider C:N ratio and fertilizer nitrogen in form of urea were used in different combinations. The physical and chemical properties of fly ash, spent mushroom composts and experimental soil are presented in Table 1.

\subsection{Treatment Imposition}

The treatment comprised of different fly ash, spent mushroom compost and fertilizer nitrogen levels added alone or in different combinations. Fly ash was applied @ $20 \mathrm{t} \mathrm{ha}^{-1}$, organic compost i.e. white button spent mushroom compost (WBSMC) with narrow C:N ratio and oyster spent mushroom compost (OYSMC) with wider C:N ratio were applied@ $5 \mathrm{t} \mathrm{ha}^{-1}$ and fertilizer nitrogen in the form of urea was applied @120 kg ha ${ }^{-1}$. A total of 12 treatments were arranged in a randomized block design with three replications. Treatments were randomly arranged to asses their individual as well as combined effects while the control was included for comparison. Fly ash and spent mushroom composts were incorporated manually with the help of spade in to the top $25 \mathrm{~cm}$ depth of soil. Fly ash and spent mushroom compost were applied 15 days before the transplanting of rice. However 
half dose of fertilizer nitrogen was applied as basal at the time of final puddling while the remaining half dose of fertilizer nitrogen was added in two equal splits at tillering and panicle initiation stage. Recommended dose of phosphorus $\left(\mathrm{P}_{2} \mathrm{O}_{5}\right)$ and potassium $\left(\mathrm{K}_{2} \mathrm{O}\right) @ 26.00$ and $42.00 \mathrm{~kg} \mathrm{ha}^{-1}$ respectively were applied as single super phosphate and muriate of potash to every individuals plot. The 25 days old seedlings were transplanted in to puddled soil at a spacing of $20 \times 15 \mathrm{~cm}$ between rows and plants. Ideal rice soil condition was maintained by providing a shallow submergence level $6 \pm 2 \mathrm{~cm}$ depth of water throughout the crop growth period.

\subsection{Paddy and Straw Yield}

Paddy and Straw yield were recorded from the net plot of $2.5 \mathrm{~m}^{2}$. Harvested grain was weighed and yield was reported at $14 \%$ moisture content.

\subsection{Plant and Soil Chemical Analysis}

The nitrogen content of grain and straw was estimated by modified Kjeldhal method (Champan and Pratt, 1961). Heavy metals i.e. Cd, Ni, and $\mathrm{Zn}$ were estimated by using triacid digestion method (Jackson, 1973). For soil chemical analysis, samples were collected from $30 \mathrm{~cm}$ depth from each plot with the help of screw auger. The samples after air drying at room temperature for 4 days were ground finely and passed through $2 \mathrm{~mm}$ sieve to determine total nitrogen content by applying modified Kjeldhal method (Champan and Pratt, 1961). While for determining the metal fractionations (Tessier et al., 1979) method was used. The relative mobility index of heavy metals was calculated by doing summations of exchangeable fraction and carbonate bond fraction of the soil.

\subsection{Statistical Analysis}

The data relating to the observed characteristics of rice crop was analyzed statistically by applying analysis of variance for Randomized Blok Design (RBD). CD was noted at the 5\% level of probability, whereas significance was indicated by F-test (Gomez and Gomez, 1983). For statistical analysis, MSTAT-C package program was used.

\section{Result and Discussion}

\subsection{Effect of Nutrient Sources on Paddy and Straw Yield}

Paddy and straw yields were higher in all the treatments except oyster spent mushroom compost (OYSMC) alone or its combination with fly ash as compared to control. The lack of response in presence of OYSMC could be attributed to its wider $\mathrm{C}: \mathrm{N}$ ratio and slow decomposition in case of coarse textured soil. Application of fly ash alone was not effective in increasing the yield of paddy and straw over control (Table 2). Fly ash used was poor in nitrogen due to loss of this nutrient during coal combustion. This nutrient was limiting in soil, which might be responsible for lower response of fly ash when applied alone. The response was significant in increasing the paddy and straw yield of rice when fly ash was used in combination with narrow ratio WBSMC and fertilizer nitrogen. The increase in paddy and straw yields due to fly ash were 106.59 and $123.32 \%$ respectively in year 2005 when used with WBSMC and nitrogen fertilizer as compared to control. Integrated use of fly ash, WBSMC and fertilizer nitrogen could supply substrate and nutrient for microbial growth in the soil low in organic carbon. Improved microbial activity might have enhanced release of nutrient in better synchrony with the demand of growing plant under integrative use of fly ash, WBSMC and fertilizer nitrogen, hence increased the crop yield. Paddy and straw yield were increased by 15.12 and $16.89 \%$ owing to combined application of fly ash, WBSMC and fertilizer nitrogen compared with the use of fertilizer nitrogen alone. Jala and Goyal (2006), also reported that conjunction with organic manure and microbial inoculants, fly ash can enhance plant biomass production from degraded soils. Comparing the effect of organic wastes, the treatments involving WBSMC were superior to the OYSMC when used alone or in combinations with other nutrient sources. The findings are in accordance with those of (Maynard, 1993), who reported that well composted organic amendments with narrow C:N ratio might release nutrients in better synchrony with the demand of growing plants. On the contrary, the treatments receiving OYSMC recorded lower paddy and straw yield which might be attributed to immobilization of native soil nitrogen in this treatment because of wider C:N ratio. (Dar et al., 2009).

\subsection{Effect of Different Nutrient Sources on Heavy Metal Content, Nitrogen Uptake and on Soil Properties}

The content of $\mathrm{Cd}$ and $\mathrm{Zn}$ in grain was less than in straw; the opposite was true for Ni. Higher uptake of $\mathrm{Cd}$ and $\mathrm{Ni}$ by rice grain and straw grown on fly ash amended soil was recorded as compared to those treated with spent mushroom compost of varied $\mathrm{C}: \mathrm{N}$ ratios or fertilizer nitrogen. In case of $\mathrm{Zn}$ the decrease in concentration was maximum in nitrogen fertilizer followed by fly ash as compared to OYSMC of wider C:N ratio and least decrease was observed in WBSMC having narrow $\mathrm{C}: \mathrm{N}$ ratio. The content of $\mathrm{Cd}$ and $\mathrm{Ni}$ increased under the combined application of fly ash with varied $\mathrm{C}: \mathrm{N}$ ratio spent mushroom composts as compared to use of fly ash with fertilizer nitrogen. Concentration of $\mathrm{Cd}, \mathrm{Ni}$ and $\mathrm{Zn}$ in rice grain and straw were highest in the treatment 
comprising application of fertilizer nitrogen with fly ash and WBSMC (Table 3). Le et al., (2006) also concluded that fly ash could be mixed with as a supplement with other nutrient sources to improve nutrient balance and their uptake in paddy soils. The increase in content of $\mathrm{Cd}, \mathrm{Ni}$ and $\mathrm{Zn}$ ranged from 0.074-0.149, 1.37-2.69 and $26.60-40.40 \mathrm{mg} \mathrm{kg}^{-1}$ respectively in grain and $0.123-0.199,0.61-2.16$ and $35.00-45.20 \mathrm{mg} \mathrm{kg}^{-1}$ respectively in straw. OYSMC suppressed the content of $\mathrm{Cd}, \mathrm{Ni}$ and $\mathrm{Zn}$ as compared to WBSMC when applied alone or in combinations with fly ash or fertilizer nitrogen. This might be due to immobilization of $\mathrm{Cd}, \mathrm{Ni}$ and $\mathrm{Zn}$ by wider $\mathrm{C}: \mathrm{N}$ ratio of OYSMC.

The increase in nitrogen uptake by grain and straw due to application of fly ash was mainly due to greater production of grain and straw as no appreciable change in nitrogen concentration of grain and straw under fly ash was observed. Similar findings were reported by (Sharma and Mitra, 1990). Uptake of nitrogen by grain and straw decreased even as compared to control when OYSMC was applied alone or in combination with fly ash whereas among composts WBSMC exhibited maximum nitrogen uptake. The reason for high nitrogen uptake by grain and straw due to application of WBSMC was its narrow C:N ratio which enhanced supply of nitrogen and improved overall soil ambience for plant growth whereas wider C:N ratio of OYSMC might have resulted in initial nitrogen starvation because of microbial immobilization of nitrogen. The results corroborate with findings of (Sangwan, et al., 2002). Sole application of fertilizer nitrogen increased nitrogen uptake by grain and straw not only by promoting dry matter production but also by increasing the nitrogen concentration of grain and straw. When fertilizer nitrogen was applied with OYSMC of wider C:N ratio the uptake of nitrogen was even lower than individual application of fertilizer nitrogen because of immobilization of applied nitrogen and lower grain and straw yields. The maximum nitrogen uptake occurred under integrative use of fertilizer nitrogen with fly ash and WBSMC (Table 4). The increase might be due to integrative role by providing conducive physical environment, improvement in soil biochemical properties which in turn facilitated more nitrogen uptake by grain and straw.

Bulk density was significantly reduced with both types of the spent mushroom compost compared with urea $\mathrm{N}$ only or the untreated control (Table 4). Application of $\mathrm{N}$ fertilizer and spent mushroom composts enhanced soil organic $\mathrm{C}$ concentrations. The effect of OYSMC on soil organic $\mathrm{C}$ was much greater than that of WBSMC and masked effects of the latter. This was due to the wider C:N ratio of the OYSMC, which was negatively correlated to $\mathrm{C}$ mineralization and positively related to immobilization (Aulakh et al., 2001). Enhanced fertilizer $\mathrm{N}$ increased the amount of crop stubble which ultimately contributed to increased soil organic $\mathrm{C}$ concentration. Soil organic $\mathrm{C}$ concentration decreased from the start of the experiment in plots that did not receive spent mushroom composts.

\subsection{Effect of Different Nutrient Sources on Different Metal Fractions and Their Relative Mobility Index}

The exchangeable, carbonate bound fraction and relative mobility index of $\mathrm{Zn}$ increased and its residual and oxide bound fraction decreased due to use of fertilizer nitrogen and fly ash where as its exchangeability, carbonate, oxide bound fraction and relative mobility index decreased and residual fraction increased as compared to control under the use of varied $\mathrm{C}: \mathrm{N}$ ratio spent mushroom composts. There was a significant increase in organic matter bound $\mathrm{Zn}$ fraction as compared to control under individual application of varied C:N ratio spent mushroom composts or when used in combination with fly ash or fertilizer nitrogen particularly in OYSMC . Exchangeable $\mathrm{Zn}$ and oxide bound fraction increased in the plots applied with fertilizer nitrogen in combination with fly ash where as exchangeable $\mathrm{Zn}$ fraction was low and carbonate bound fraction was high when spent mushroom composts especially one with wider C:N ratio (OYSMC) was used either with fertilizer nitrogen or fly ash or both of them. The relative mobility index of $\mathrm{Zn}$ decreased in treatments comprising the use of varied C:N ratio composts and increased in fly ash based treatments, alone or in combination with fertilizer nitrogen (Table 5). As the contamination increased the proportion of $\mathrm{Zn}$ in residual fraction tends to decrease and that of oxide bound fraction increased. The most obvious aspect of the data for fly ash and compost added $\mathrm{Zn}$ is that it was distributed mostly in exchangeable and organic matter bound fractions. The lower $\mathrm{Zn}$ in exchangeable fraction compared with control for OYSMC and WBSMC were evident as is the fact that the $\mathrm{Zn}$ was higher in oxide bound form. The most stable compost (OYSMC) had the lowest soluble carbon content than WBSMC, the soluble carbon compounds acting as chelating agents for $\mathrm{Zn}$ which have increased $\mathrm{Zn}$ in solution phase. The most stable solid material i.e. OYSMC did provide adsorption sites for $\mathrm{Zn}$ so decreased its bioavailability. Similar findings were earlier reported by (Shuman, 1999).

The distribution of $\mathrm{Cd}$ between different fractions shows that the greater amount of $\mathrm{Cd}$ are in exchangeable, residual, oxide and carbonate bound fractions with the smallest amount of $\mathrm{Cd}$ being associated with organic matter bound fraction. The exchangeable amount of $\mathrm{Cd}$ increased and carbonate bound fraction decreased due to use of fertilizer nitrogen, composts and fly ash alone or in combinations as that of control. The increase was 
maximum in the treatment comprising the application of fly ash and minimum in case of treatments being applied with fertilizer nitrogen and OYSMC of wider C:N ratio (Table 5). The percentage of oxide bound fraction increased due to use of fly ash or nitrogen whereas it decreased by the application of varied C:N ratio composts. The organic matter bound fractions of $\mathrm{Cd}$ increased significantly in the treatments including fertilizer nitrogen and composts of varied $\mathrm{C}: \mathrm{N}$ ratio where as under the use of fly ash the increase was non significant. The residual $\mathrm{Cd}$ fractionation decreased due to different nutrient sources, the decrease was higher in fly ash applied treatments. Relative mobility index of $\mathrm{Cd}$ decreased when different nutrient sources were used alone or in combinations as that of control. It seems that polluted inputs of $\mathrm{Cd}$ are in the form of oxides and have effectively diluted to contribute to form the residual fraction. The higher percentage in exchangeable phase represents the mobile and bioavailable fraction. In this phase $\mathrm{Cd}$ has more liable bonds and can be more easily released if carbonate and organic matter bound fractions cannot be increased. Cd showed the highest performance to form easily soluble bonds that is why the percentage of $\mathrm{Cd}$ in the non residual fraction was much greater than that of residual fraction. The findings are in conformity with those of (Lena and Tam, 1997).

The distribution of Ni between different fractions reflects that greater amount of Ni was associated with residual fraction followed by oxide and exchangeable fractions where as least was in organic matter bound form. The exchangeable fraction was maximum under sole application of fly ash, when used with fertilizer nitrogen and varied $\mathrm{C}: \mathrm{N}$ ratio composts the effect of fly ash on exchangeability was reduced. Carbonate bound fraction of $\mathrm{Ni}$ decreased due to individual effect of different nutrient sources and by their interactions. The oxide bound fraction of $\mathrm{Ni}$ decreased due to application of fertilizer nitrogen and composts of varied $\mathrm{C}: \mathrm{N}$ ratio where as increased by applying fly ash. Organic matter bound fraction increased as that of control under use of different nutrient sources, but the treatments comprising application of composts and fertilizer nitrogen have higher organic matter bound fraction where least occurred under use of fly ash (Table 5). The residual fraction was by far the most important fraction of $\mathrm{Ni}$ in soil and in enhanced with increasing contamination. The maximum residual fraction of $\mathrm{Ni}$ was observed in fly ash applied plots. Relative mobility index of $\mathrm{Ni}$ decreased significantly under use of OYSMC as that of control. The findings are in accordance with those of (Lena and Tam, 1997).

\section{Conclusion}

Varied C:N ratio organic composts having high organic carbon content and micronutrients when used in conjunction with inorganic fertilizer nitrogen and fly ash can improve soil properties and release nutrients in better synchrony with the demand of growing crop to enhance productivity. They also form the organic-metal complexes to reduce the bioavailability of metals applied through fly ash by providing adsorption sites to these health hazardous elements of food chain. So the joint use of these varied C:N ratio composts and fly ash can lead to have better scope of using waste materials by having synergetic effect on soil properties and reduction in metal bioavailability .

\section{References}

Aulakh, M. S., Khera, T. S., Doran, J. W., \& Bronson, F. (2001). Managing crop residue with green manure, urea and tillage in rice-wheat rotation. Soil Science Society of American Journal, 65, 820-827. http://dx.doi.org/10.2136/sssaj2001.653820x

Ayeni, L. S. (2011). Integrated Plant Nutrition Management: A Panacea for Sustainable Crop Production in Nigeria. International Journal of Soil Science, 6, 19-24. http://dx.doi.org/10.3923/ijss.2011.19.24

Azmal, A. K. M., Marumoto, T., Shinde, H., \& Nishiyama, M. (1996). Mineralization and microbial biomass formation in upload soil amended with some tropical plant residues at different treatments. Soil Science and Plant Nutrition, 42, 463-473. http://dx.doi.org/10.1080/00380768.1996.10416315

Blacke, G. R., \& Hartage, K. H. (1986b). Particle density, 377-382. In (A. Klute ed.) Methods of Soil Analysis Part $1,2^{\text {nd }}$ edition. Agronomy Monograph No. 9. American Society of Agronomy and Soil Science Society of Agronomy. Madison, Wisconsin.

Champan, H. D., \& Pratt, P. F. (1961). Methods for Analysis of Soil, Plants and water. Univ. of California, USA.

Dar, S. R., Thomas, T., Khan, I. M., Dagar, J. C, Quadar, A., \& Rashid, M. (2009). Effect of nitrogen fertilizer with mushroom compost of varied $\mathrm{C}: \mathrm{N}$ ratio on nitrogen use efficiency, carbon sequestration and rice yield. Communications in Biometry and Crop Science, 4(1), 31-39.

Elseewi, A. A., Bingham, F. T., \& Page, A. L. (1980). Sequential cropping of fly ash amended soils: effect on soil chemical properties and yield and elemental composition of plants. Science of Total Environment, 15, 247-259. http://dx.doi.org/10.1016/0048-9697(80)90053-4 
Fisher, G. L., Chang, D. P. Y., \& Brumer, M. (1976). Flyash collected from electrostatic precipitation: microcrystalline structure and the mystery of the spheres. Science Washington, D.C, 129, 553-555. http://dx.doi.org/10.1126/science.192.4239.553

Gomez, K. A., \& Gomez, A. A. (1983). Statistical Procedures for Agricultural Research. John Wilkey and Sons Singapore $680 \mathrm{pp}$.

Hill, M. J., \& Camp, C. A. (1984). Use of pulverized fuel ash from Victoria brown coal as a source of nutrient for pasture species. Australian Journal of Experimental Agriculture and Animal Husbandary, 30, 377-384.

Jackson, M. L. (1973). Soil Chemistry Analysis second ed. Prentice Hall of India Pvt. Ltd, New Delhi.

Jala, S., \& Goyal, D. (2006). Fly ash as a soil ameliorant for improving crop production-a review. Bioresource Technology, 97, 1136-1147. http://dx.doi.org/10.1016/j.biortech.2004.09.004

Law Ogbomo, K. E., Remison, S. U., \& Jombo, E. O. (2011). Effects of organic and inorganic fertilizers on the productivity of Amaranthus cruents in an ultisol environment. International Journal of Plant Physiology and Biochemistry, 3, 247-252. http://dx.doi.org/10.5897/IJPPB11.028

Lee, H., Ha, H. S., Lee, C. H., Lee, Y. B., \& Kim, P. J. (2006). Fly ash effect on improving soil properties and rice productivity in Korean paddy soils. Bioresource Technology, 97, 1490-1497. http://dx.doi.org/10.1016/j.biortech.2005.06.020

Lena, Q. M., Tam, \& Haris, W. G. (1997). Concentration and distribution of eleven metals in Florida soils. Journal of Environmental Quality, 26, 769-775. http://dx.doi.org/10.2134/jeq1997.263769x

Marten, D. C. (1971). Availability of plant nutrients in fly ash. Compost Science, 12, 15-19.

Maynard, A. A. (1993). Sustainable vegetable production for three years using composted animal manure. Compost Science and Utilisation, 2, 88-96.

Olsen S. R., \& Sommers L. E. (1982). Phosphorus. Pages 403-431 in A.L. Page, ed. Methods of soil analysis. Part 2. 2nd ed. Agronomy Monogram. 9 American Society of Agronomy and Soil Science Society of Agronomy. Madison, Wisconsin.

Pankaj, D., Manoj, P., \& Noval, K. (2010). Utilization of fly ash as a structural fill material for safe and sustainable development: Need of hour. The Indian Mining and Engineering Journal, 134-139.

Piper, S. C. (1950). Soil and plant analysis. University of Adelaide Press, Australia.

Randsome, L. S., \& Dowdy, R. H. (1987). Soyabean growth and boron distributionin sandy soils amended with scrubber sludge. Journal of Environmental Quality, 16, 171-175. http://dx.doi.org/10.2134/jeq1987.00472425001600020014x

Roy, R. N. (1994). In fertilizers, organic manures, recyclable wastes and biofertilizers components of integrated plant nutrition. (ed.) H.L.S. Tandon. FDCO, New Delhi, 1-11.

Sangwan, P. S., Swami, S., Singh, J. P., Kuhad, M. S., \& Dahiya, S. S. (2002). Effect of spent mushroom composts and inorganic fertilizers on the yield and nutrient uptake by wheat. Journal of Indian Society of Soil Science, 50, 186-189.

Schnappinger, M. F., Martens, D. C., \& Plank, C. D. (1975). Zinc availability as influenced by application of fly ash to soil. Environmental Science and Technology, 9, 258-261. http://dx.doi.org/10.1021/es60101a009

Sharma, A. R., \& Mitra, B. N. (1990). Complementary effect of organic, bio and mineral fertilizers on rice based cropping system. Fertiliser News, 32, 43-51.

Shuman., Larry, M. (1999). Effect of organic waste amendments on Zn adsorption by two soils. Soil Science, 164, 197-205.

Sikka, R., \& Kansal, B. D. (1995). Effect of fly ash application on yield and nutrient composition of rice, wheat and on $\mathrm{pH}$ and available nutrient status of soils. Bioresource Technology, 51, 199-203. http://dx.doi.org/10.1016/0960-8524(94)00119-L

Stewart, D. P. C., Camerson, K. C., Cornoforth, I. S., \& Sedcole, J. R. (1998). Effect of spent mushroom substrate on soil chemical conditions and plant growth as an intensive horticultural system: a comparison with inorganic fertilizers. Australian Journal of Soil Research, 36, 185-198. http://dx.doi.org/10.1071/S97076

Subbiah, B. U., \& Asijia, G. L. (1956). A rapid procedure for the estimation of available nitrogen in soils. Current Science, 25, 259-260. 
Tessier, A., Cambell, P. G. C., \& Bissan, M. (1979). Sequential extractionprocedure for the speciation of particulate trace metals. Analytical Chemistry, 51, 844-851. http://dx.doi.org/10.1021/ac50043a017

Trierweiter, J. R., \& Lindsay, W. L. (1968). EDTA- ammonium carbonate soil test for Zn. Soil Science Society of American Journal, 85, 302-306.

Table 1. Physical and chemical properties of fly ash, spent mushroom composts and experimental soil

\begin{tabular}{llllll}
\hline Particulars & Fly ash & WBSMC & OYSMC & Soil & \multicolumn{1}{c}{ Method used } \\
\hline Sand \% (W/W) & 35.00 & - & - & 62.25 & Pipette method (Piper, 1950) \\
Silt \% (W/W) & 53.30 & - & - & 23.79 & \\
Clay \% (W/W) & 11.70 & - & - & 13.96 & \\
Bulk density $\left(\mathrm{Mgm}^{-3}\right)$ & 1.05 & 0.26 & 0.20 & 1.58 & Blacke and Hartage, 1986 \\
Water holding capacity \% & 61.35 & $\mathrm{Nd}$ & $\mathrm{Nd}$ & 50.80 & Keen-Raczkowskibox (Piper, \\
$(\mathrm{W} / \mathrm{W})$ & & & & & $1950)$ \\
$\mathrm{pH}(1: 2 \mathrm{~W} / \mathrm{V}$ water) & 7.97 & 7.26 & 7.43 & 7.80 & Digital pH meter \\
Organic carbon $\left(\mathrm{g} \mathrm{kg}^{-1}\right)$ & 1.25 & 169.90 & 184.15 & 4.20 & Walkely and Black $\quad$ (Jackson, \\
& & & & & $1973)$ \\
C/N ratio & 12.50 & 15.17 & 37.59 & 5.25 & - \\
Cation exchange capacity $(\mathrm{Cmol}$ & 1.91 & 61.11 & 40.70 & 21.40 & Jackson, 1973 \\
$\left.\mathrm{kg}^{-1}\right)$ & & & & & \\
Total N $\left(\mathrm{g} \mathrm{kg}^{-1}\right)$ & 0.10 & 11.20 & 5.25 & 0.65 & Chappman and Pratt, 1961 \\
Available N $\left(\mathrm{mg} \mathrm{kg}^{-1}\right)$ & 17.35 & $\mathrm{Nd}$ & $\mathrm{Nd}$ & 110.00 & Subbiah and Asijia, 1956 \\
Total P $\left(\mathrm{g} \mathrm{kg}^{-1}\right)$ & 0.70 & 7.85 & 1.57 & 0.57 & Jackson, 1973 \\
Available P $\left(\mathrm{mg} \mathrm{kg}^{-1}\right)$ & 14.85 & $\mathrm{Nd}$ & $\mathrm{Nd}$ & 11.00 & Olsen and Sommers, 1982 \\
Total K $\left(\mathrm{g} \mathrm{kg}^{-1}\right)$ & 4.00 & 20.35 & 12.05 & 3.40 & Chappman and Pratt, 1961 \\
Available K $\left(\mathrm{mg} \mathrm{kg}^{-1}\right)$ & 290.00 & $\mathrm{Nd}$ & $\mathrm{Nd}$ & 187.00 & Jackson, 1973 \\
Total Zn $\left(\mathrm{mg} \mathrm{kg}^{-1}\right)$ & 63.66 & 180.00 & 140.50 & 64.14 & Trierweiter and Lindsay, 1968 \\
Total Cd $\left(\mathrm{mg} \mathrm{kg}^{-1}\right)$ & 40.58 & 1.69 & 1.72 & 3.64 & \\
Total Ni $\left(\mathrm{mg} \mathrm{kg}^{-1}\right)$ & 144.99 & 12.39 & 11.00 & 22.36 & \\
\hline
\end{tabular}

Table 2. Effect of different nutrient sources on paddy and straw yield (tones ha ${ }^{-1}$ ) of rice

\begin{tabular}{lllllll}
\hline Nutrient sources & \multicolumn{3}{c}{2004} & & \multicolumn{3}{c}{ Pooled } \\
\cline { 2 - 7 } & Paddy & Straw & Paddy & Straw & Paddy & Straw \\
\hline Control & 2.70 & 3.28 & 2.58 & 3.13 & 2.64 & 3.20 \\
$\mathrm{~N}_{120}$ & 4.59 & 5.83 & 4.63 & 5.98 & 4.61 & 5.90 \\
WBSMC $_{5}$ & 3.39 & 4.25 & 3.43 & 4.31 & 3.41 & 4.28 \\
OYSMC $_{5}$ & 2.25 & 2.58 & 2.20 & 2.49 & 2.22 & 2.54 \\
Fly ash $_{20}$ & 2.79 & 3.45 & 2.64 & 3.27 & 2.71 & 3.36 \\
$\mathrm{~N}_{120}+\mathrm{WBSMC}_{5}$ & 5.22 & 6.74 & 5.29 & 6.85 & 5.26 & 6.80 \\
$\mathrm{~N}_{120}+\mathrm{OYSMC}_{5}$ & 4.14 & 5.26 & 4.19 & 5.38 & 4.17 & 5.32 \\
$\mathrm{~N}_{120}+$ Fly ash $_{20}$ & 4.63 & 5.89 & 4.65 & 6.03 & 4.64 & 5.96 \\
WBSMC $_{5}+$ Fly ash $_{20}$ & 3.48 & 4.34 & 3.51 & 4.46 & 3.49 & 4.40 \\
OYSMC $_{5}+$ Fly ash $_{20}$ & 2.32 & 2.73 & 2.29 & 2.60 & 2.31 & 2.67 \\
$\mathrm{~N}_{120}+$ WBSMC $_{5}+$ Fly ash $_{20}$ & 5.25 & 6.98 & 5.33 & 6.99 & 5.29 & 6.99 \\
$\mathrm{~N}_{120}+$ OYSMC $_{5}+$ Fly ash $_{20}$ & 4.22 & 5.38 & 4.24 & 5.42 & 4.22 & 5.40 \\
CD $(\mathrm{P}=0.05)$ & 0.90 & 1.89 & 0.75 & 1.60 & 0.86 & 1.74 \\
\hline
\end{tabular}


Table 3. Heavy metal content $\left(\mathrm{mg} \mathrm{kg}^{-1}\right)$ of paddy and straw as influenced by different nutrient sources

\begin{tabular}{|c|c|c|c|c|c|c|c|c|c|c|c|c|c|c|c|c|c|c|}
\hline \multirow[t]{3}{*}{ Nutrient sources } & \multicolumn{6}{|c|}{$\mathrm{Cd}$} & \multicolumn{6}{|c|}{$\mathrm{Ni}$} & \multicolumn{6}{|c|}{$\mathrm{Zn}$} \\
\hline & \multicolumn{3}{|c|}{ Paddy } & \multicolumn{3}{|c|}{ Straw } & \multicolumn{3}{|c|}{ Paddy } & \multicolumn{3}{|c|}{ Straw } & \multicolumn{3}{|c|}{ Paddy } & \multicolumn{3}{|c|}{ Straw } \\
\hline & 2004 & 2005 & Pooled & 2004 & 2005 & Pooled & 2004 & 2005 & Pooled & 2004 & 2005 & Pooled & 2004 & 2005 & Pooled & 2004 & 2005 & Pooled \\
\hline Control & 0.079 & 0.074 & 0.076 & 0.129 & 0.123 & 0.126 & 1.44 & 1.37 & 1.40 & 0.65 & 0.61 & 0.63 & 28.80 & 26.60 & 27.70 & 36.10 & 35.00 & 35.55 \\
\hline $\mathrm{N}_{120}$ & 0.087 & 0.082 & 0.084 & 0.137 & 0.132 & 0.134 & 1.51 & 1.47 & 1.49 & 0.77 & 0.73 & 0.75 & 29.40 & 27.30 & 28.35 & 36.50 & 35.30 & 35.90 \\
\hline WBSMC $_{5}$ & 0.106 & 0.100 & 0.103 & 0.157 & 0.149 & 0.153 & 1.76 & 1.72 & 1.74 & 1.19 & 1.19 & 1.19 & 37.80 & 37.50 & 37.65 & 43.50 & 43.80 & 43.65 \\
\hline $\mathrm{OYSMC}_{5}$ & 0.093 & 0.086 & 0.089 & 0.140 & 0.136 & 0.138 & 1.57 & 1.54 & 1.55 & 0.97 & 0.94 & 0.95 & 34.30 & 33.20 & 33.75 & 39.10 & 39.50 & 39.30 \\
\hline Fly $\operatorname{ash}_{20}$ & 0.120 & 0.123 & 0.121 & 0.164 & 0.168 & 0.166 & 2.03 & 2.16 & 2.09 & 1.52 & 1.64 & 1.58 & 32.70 & 30.00 & 31.35 & 37.20 & 36.80 & 37.00 \\
\hline $\mathrm{N}_{120}+\mathrm{WBSMC}_{5}$ & 0.113 & 0.109 & 0.111 & 0.162 & 0.155 & 0.158 & 1.80 & 1.86 & 1.83 & 1.27 & 1.34 & 1.30 & 38.30 & 38.30 & 38.30 & 43.80 & 44.20 & 44.00 \\
\hline $\mathrm{N}_{120}+\mathrm{OYSMC}_{5}$ & 0.100 & 0.097 & 0.098 & 0.149 & 0.144 & 0.146 & 1.68 & 1.61 & 1.64 & 1.13 & 1.07 & 1.10 & 34.70 & 33.50 & 34.10 & 39.60 & 39.60 & 39.60 \\
\hline $\mathrm{N}_{120}+$ Fly $\operatorname{ash}_{20}$ & 0.125 & 0.131 & 0.128 & 0.171 & 0.176 & 0.173 & 2.15 & 2.28 & 2.21 & 1.66 & 1.71 & 1.68 & 33.10 & 30.60 & 31.85 & 37.70 & 37.40 & 37.55 \\
\hline $\begin{array}{c}\mathrm{WBSMC}_{5}+\text { Fly } \\
\mathrm{ash}_{20}\end{array}$ & 0.140 & 0.142 & 0.141 & 0.184 & 0.193 & 0.188 & 2.47 & 2.58 & 2.52 & 1.96 & 2.03 & 1.99 & 39.20 & 39.50 & 39.35 & 44.50 & 44.90 & 44.70 \\
\hline $\begin{array}{c}\mathrm{OYSMC}_{5}+\text { Fly } \\
\operatorname{ash}_{20}\end{array}$ & 0.131 & 0.134 & 0.132 & 0.175 & 0.181 & 0.178 & 2.21 & 2.34 & 2.27 & 1.73 & 1.76 & 1.74 & 35.40 & 34.40 & 34.80 & 40.40 & 40.70 & 40.55 \\
\hline $\begin{array}{c}\mathrm{N}_{120}+\mathrm{WBSMC}_{5} \\
+ \text { Fly ash }_{20}\end{array}$ & 0.144 & 0.149 & 0.146 & 0.192 & 0.199 & 0.195 & 2.64 & 2.69 & 2.66 & 2.11 & 2.16 & 2.13 & 39.80 & 40.40 & 40.10 & 45.00 & 45.20 & 45.10 \\
\hline $\begin{array}{c}\mathrm{N}_{120}+\mathrm{OYSMC}_{5} \\
+ \text { Fly ash } \\
20\end{array}$ & 0.137 & 0.137 & 0.137 & 0.180 & 0.187 & 0.183 & 2.36 & 2.43 & 2.39 & 1.88 & 1.92 & 1.90 & 36.00 & 35.20 & 35.60 & 40.90 & 41.10 & 41.00 \\
\hline $\mathrm{CD}(\mathrm{P}=0.05)$ & 0.027 & 0.030 & 0.034 & 0.026 & 0.037 & 0.031 & 0.36 & 0.42 & 0.53 & 0.58 & 0.61 & 0.62 & 1.18 & 1.28 & 1.10 & 0.90 & 1.05 & 1.14 \\
\hline
\end{tabular}

Table 4. Effect of different nutrient sources on the uptake of nitrogen by grain and straw and on bulk density and soil organic carbon content

\begin{tabular}{|c|c|c|c|c|c|c|c|c|}
\hline & \multicolumn{2}{|l|}{2004} & \multicolumn{2}{|l|}{2005} & \multicolumn{2}{|l|}{ Pooled } & \multirow{2}{*}{$\begin{array}{l}\text { Pooled } \\
\text { Soil bulk density } \\
\quad\left(\mathrm{Mg} \mathrm{m}^{-3}\right)\end{array}$} & \multirow{2}{*}{$\begin{array}{l}\text { Pooled } \\
\begin{array}{l}\text { Soil organic carbon } \\
\left(\mathrm{g} \mathrm{kg}^{-1} \text { soil }\right)\end{array} \\
\end{array}$} \\
\hline & $\begin{array}{l}\text { Paddy } \\
\left(\mathrm{kg} \mathrm{ha}^{-1}\right)\end{array}$ & $\begin{array}{l}\text { Straw } \\
\left(\mathrm{kg} \mathrm{ha}^{-1}\right)\end{array}$ & $\begin{array}{l}\text { Paddy } \\
\left(\mathrm{kg} \mathrm{ha}^{-1}\right)\end{array}$ & $\begin{array}{l}\text { Straw } \\
\left(\mathrm{kg} \mathrm{ha}^{-1}\right)\end{array}$ & $\begin{array}{l}\text { Paddy } \\
\left(\mathrm{kg} \mathrm{ha}^{-1}\right)\end{array}$ & $\begin{array}{l}\text { Straw } \\
\left(\mathrm{kg} \mathrm{ha}^{-1}\right)\end{array}$ & & \\
\hline Control & 29.70 & 18.64 & 26.60 & 16.90 & 28.15 & 17.77 & 1.62 & 3.50 \\
\hline $\mathrm{N}_{120}$ & 67.80 & 39.74 & 70.80 & 41.40 & 69.30 & 40.57 & 1.61 & 3.95 \\
\hline WBSMC $_{5}$ & 48.10 & 29.40 & 50.30 & 32.80 & 49.20 & 31.10 & 1.54 & 4.20 \\
\hline $\mathrm{OYSMC}_{5}$ & 25.15 & 13.32 & 24.19 & 12.30 & 24.67 & 12.81 & 1.53 & 4.82 \\
\hline Fly $\operatorname{ash}_{20}$ & 30.40 & 20.01 & 29.22 & 18.64 & 29.81 & 19.32 & 1.60 & 3.60 \\
\hline $\mathrm{N}_{120}+\mathrm{WBSMC}_{5}$ & 90.50 & 60.72 & 93.10 & 69.70 & 91.80 & 65.21 & 1.53 & 4.64 \\
\hline $\mathrm{N}_{120}+\mathrm{OYSMC}_{5}$ & 64.60 & 36.88 & 66.80 & 38.50 & 65.70 & 37.69 & 1.52 & 5.21 \\
\hline $\mathrm{N}_{120}+$ Fly $\operatorname{ash}_{20}$ & 69.80 & 40.58 & 72.40 & 42.10 & 71.10 & 41.34 & 1.59 & 3.98 \\
\hline $\mathrm{WBSMC}_{5}+$ Fly ash $_{20}$ & 50.40 & 29.60 & 51.80 & 33.00 & 51.10 & 31.30 & 1.50 & 4.25 \\
\hline $\mathrm{OYSMC}_{5}+$ Fly ash $_{20}$ & 25.60 & 14.74 & 24.98 & 13.20 & 25.29 & 13.97 & 1.46 & 4.86 \\
\hline $\mathrm{N}_{120}+\mathrm{WBSMC}_{5}+$ Fly $\operatorname{ash}_{20}$ & 93.50 & 63.22 & 95.90 & 71.80 & 94.70 & 67.51 & 1.49 & 4.68 \\
\hline $\mathrm{N}_{120}+\mathrm{OYSMC}_{5}+$ Fly ash $_{20}$ & 66.40 & 39.56 & 67.40 & 40.20 & 66.90 & 39.88 & 1.45 & 5.23 \\
\hline $\mathrm{CD}(\mathrm{P}=0.05)$ & 0.58 & 0.46 & 0.75 & 0.98 & 0.69 & 0.74 & 0.06 & 0.24 \\
\hline
\end{tabular}


Table 5. Different metal fractions (\%) and relative mobility index (\%) of heavy metals in soil at the end of second harvest

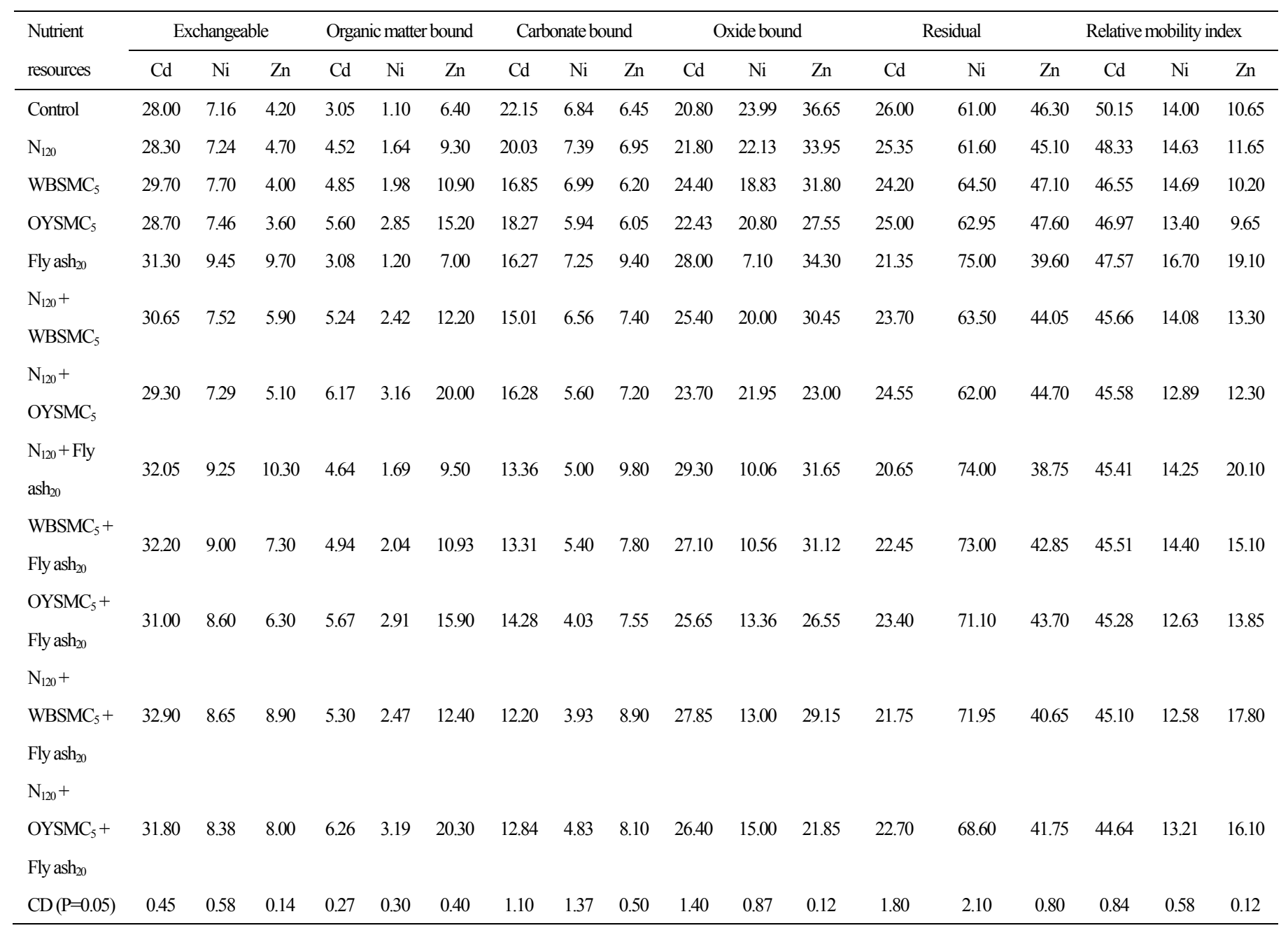

